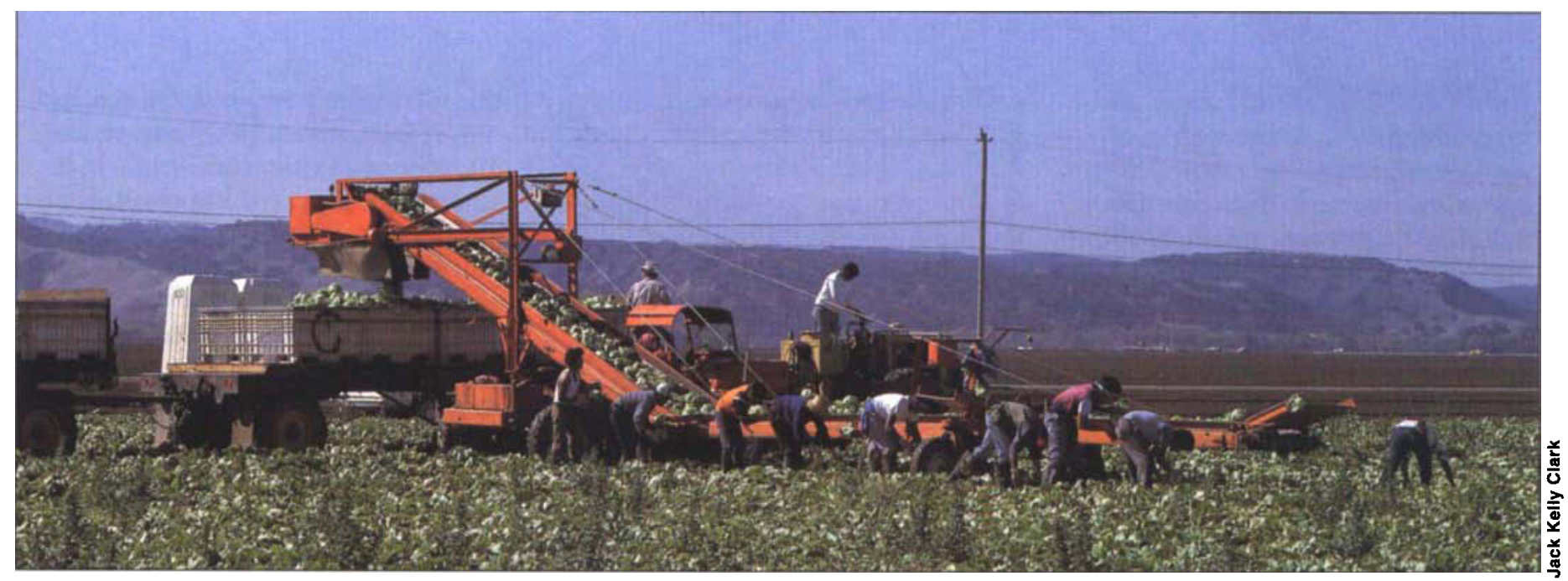

\title{
Farm labor contractors play new roles in agriculture
}

Farm labor contractors are the fastest growing employer in California agriculture, accounting for $90 \%$ of the increase in seasonal worker employment since the mid-1980s.

\author{
Dawn Thilmany $\quad$ Philip L. Martin
}

\begin{abstract}
The role of farm labor contractors in California agriculture has evolved along with changes in the state's immigration and labor policies. Today, the role of FLCs in California is expanding, due in part to an increase in farm labor regulations. Growers say they find it easier and more cost-effective to use FLCs for the recruitment and supervision of agricultural workers. Yet the issue of who is liable for labor law violations and to what extent remains in dispute. This study investigates the changing relationship between FLCs and their grower-clients.
\end{abstract}

C alifornia agriculture has long relied on intermediaries to recruit, train and supervise immigrant farmworkers who do much of the work on the state's farms. Some of California's first intermediaries were bilingual Chinese and Japanese workers who specialized in arranging seasonal farm jobs for their crews. In the 1920s, specialized labor recruiters emerged who profited from the difference between what an employer paid to get the job done and wages the workers received. Some farmworkers began to see labor contractors as their "enemies," and unions complained that labor contractors made it difficult to organize workers. Today, farm labor contractors (FLCs) supply workers to perform a variety of farm jobs, from planting and weeding to harvesting and packing crops.

About one-third of all California farmworkers have been employed through an FLC at least once during a typical year, according to state tax records. FLCs are the fastest growing employer in California agriculture, accounting for $90 \%$ of the increase in seasonal worker employment since the mid-1980s.

Government agencies in recent years have expressed some concern about the growing importance of FLCs in the farm labor market. Noting the growing role of FLCs, and the declining role of the EDD-operated Employment Service in matching seasonal workers and jobs, the Commission on Agricultural Workers expressed concern because "workers employed by [FLCs] generally receive lower wages and are employed under working conditions inferior to those offered to farmworkers hired by other agricultural employers." The commission urged that requirements be tightened to become a FLC, and that employers who knowingly use an unlicensed FLC should be held "solely liable" for any violations of labor laws.

This renewed interest in FLCs has prompted a number of surveys of FLCs, farmworkers and farm employers. This paper reports on one of the most understudied aspects of FLCs their relationships with the farmers who use them to obtain crews of seasonal workers.

\section{Trends in FLC usage}

According to California Employment Development Department data, the share of agricultural workers hired through FLCs increased by $25 \%$ between 1984 and 1988, a trend that has continued into the present day. A 1992 survey of 570 California growers found that $44 \%$ had hired at least some FLC workers, and that the share of workers hired through FLCs had increased by $46 \%$ since 1987 .

Reliance on FLCs has also grown in other states. A 1991 study found increasing use of FLCs in Florida and Texas. FLC employment in Texas increased by $48 \%$ between 1986 and 1989 while the state's fruit, vegetable and horticultural production increased only $14 \%$. 


\section{California case studies}

To examine the relationship between growers and contractors, 11 case studies were conducted in 199394 that asked growers and FLCs to explain their working relationship.

The FLCs interviewed were diverse with annual payrolls ranging from $\$ 7$ million to less than $\$ 100,000$ (table 1 ). No direct relationship existed between payroll size and number of clients served. The firm with the largest payroll had 42 clients, whereas several mid-sized firms had over 100 clients each. The FLC with the smallest payroll had three client-farmers. The "average" contractor served 45 growers in 1993 , but this average is not very meaningful due to the wide distribution in number of clients.

Most FLC payrolls were more than $\$ 2$ million. The average number of workers employed by these FLCs in 1993 was 800 , ranging from 25 to 2,000 workers. Two firms had been in business for more than 30 years; the newest FLC began operating in 1992. On average, contractors had been in business 17 years. The size and age of the FLC firms were not strongly related as evidenced by the fact that the two smallest firms represented both the youngest and the oldest FLCs in the group. Several established FLCs noted that they had been working for the same growers as long as they had been in business.

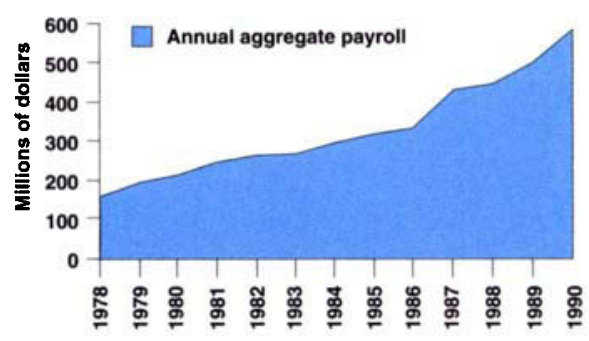

Fig. 1. California farm labor contractor annual payrolls, 1978-1990. Source: Employment Development Department, 1992.

\section{Growers pay FLCs a commission} for their services, as well as mandatory payroll taxes ranging from 15 to $30 \%$ of hourly or piece-rate earnings. (Mandatory payroll taxes include social security, unemployment insurance, and worker compensation.) Estimating commissions is difficult because the method of payment varies. Some growers separate out recruitment and supervision commissions; for example, they may pay the FLC a $12 \%$ commission based on the hourly or piece-rate wage. Others include the FLC's commission in an overall rate of roughly $40 \%$. If FLCs on average get $10 \%$ commissions for their services (a conservative estimate), then the FLCs interviewed received from $\$ 10,000$ to $\$ 350,000$ to cover their costs of recruitment, record-keeping, and, in many cases, provision of work-related equipment and field sanitation facilities.

Traditionally, most FLCs have had verbal agreements with farmers, but this relationship appears to be changing, at least among FLCs interviewed. The increased risk of enforcement liability and, perhaps, more professionalism has prompted a move toward more written contracts. The contractors studied here may have been more formally structured in their businesses. Most had at least some written contracts. In contrast, fewer than $20 \%$ of contractors interviewed statewide in 1992 had written contracts with their grower-clients.

\section{Why FLCs?}

Since farm employers have the option of calling the Employment Service to obtain workers at no charge, why are farmers willing to pay recruitment commissions to FLCs?

In a 1992 survey that limited FLC respondents to one response, the majority of FLCs (39\%) said they believed growers used them to reduce paperwork. Other major reasons given were to guarantee a labor supply, lower labor costs, and reduce liability for labor law violations.

In the most recent case studies, FLCs again indicated they believed farmers used them to reduce paperwork and to have a reliable source of labor (table 2).

There were significant differences between what FLCs believed were the reasons growers hired them and what growers reported as reasons. The rea-

TABLE 1. Summary information on farm labor contractors study participants, 1993

\begin{tabular}{|c|c|c|c|c|c|c|c|}
\hline Contractor & $\begin{array}{l}\text { Years in } \\
\text { business }\end{array}$ & Clients & Payroll & Workers* & Primary cropst & Commission rate $\ddagger$ & Contracts \\
\hline & & & $\$$ millions & & & ............................... & \\
\hline Sacramento Valley A & 31 & 3 & $<1$ & 25 & tomatoes, sugar beets & 6-10 above taxes & written \\
\hline Imperial Valley A & 28 & 50 & 2 & 300 & sugar beets, cotton, vegetables & $35-37$ & verbal \\
\hline San Joaquin Valley A & 2 & 110 & 4.5 & 1,800 & row crops, nuts, citrus, grapes & $34-37$ & written \\
\hline Imperial Valley B & 31 & 20 & 3.5 & 1,500 & sugar beets, vegetables & $33-39$ & verbal \\
\hline San Joaquin Valley B & 15 & 38 & 5 & 1,300 & garlic, citrus, tree crops & $32-33$ & written \\
\hline San Joaquin Valley C & 30 & 150 & $>3$ & 700 & grapes and tree fruit & $33-36$ & verbal \\
\hline Central Coast A & 21 & 20 & 2.5 & 200 & tomatoes, peppers, broccoli & 40 & verbal \\
\hline Central Coast B & 12 & 42 & 7 & 2,000 & artichokes, mixed vegetables & 11-12 above taxes & some written \\
\hline Imperial Valley C & 1 & 5 & .14 & $100-150$ & sugar beets, vegetables & 35 & verbal \\
\hline Central Coast C & 12 & 30 & 3.5 & 350 & vineyards, vegetables & 12 above taxes & some written \\
\hline Imperial Valley D & 7 & $25-30$ & 3 & $700-800$ & sugar beets, vegetables, cotton & 36 & some written \\
\hline EDD Study§ & NA & 15.3 & 1.2 & 280 & various & $\begin{array}{l}\text { Range } 23-63 \text {, } \\
97 \% \text { in } 30-45 \% \text { range }\end{array}$ & $\begin{array}{l}82 \% \text { used } \\
\text { no written }\end{array}$ \\
\hline
\end{tabular}

"The number of workers employed by the company during peak operating season.

tEach FLC specialized in specific crops, but the majority of contractors were diversified among 5 or 10 crops.

$\ddagger$ Commissions vary with different tasks

$\S$ A 1992 study asked similar questions of the 180 FLCs surveyed. These statistics represent averages for that group. 
son given most frequently, by $28 \%$ of growers, was to reduce their liability for labor law and immigration violations. Most of the 11 growers interviewed had been using farm labor contractors to meet at least some of their labor needs for many years. Since 1990, three had switched to hiring all their workers through FLCs. The growers all expressed concern about the increased complexity of farm labor management, including the paperwork and record-keeping required to comply with immigration and safety programs.

Some growers said they carefully check the FLCs they use because they believe growers and FLCs are jointly liable for labor and immigration violations. This increasing concern about liability, however, does not necessarily translate into higher commissions for FLCs with good reputations and records. Three FLCs we interviewed maintained that even growers who think they are completely transferring liability for labor management to FLCs continue to look for the cheapest commission rates. Several contractors noted that commission rates have dropped significantly in recent years. Several FLCs claimed that many growers will not pay a premium for quality work, so even "good" FLCs must match the lower rates of their competitors. However, most FLCs believe they can secure more business by doing quality work, and several have developed crews of well-trained, experienced laborers skilled at the careful harvest and proper packing of specific crops. Clearly, quality work helps FLCs retain customers, but does not guarantee higher wages and commissions.

\section{Region-specific effects}

Most of the largest contractors are located in California's Central Coast, the so-called "Salad Bowl" of the United States, where many of the nation's vegetables are grown. The large size of Central Coast production operations, as well as the year-round production, helps support larger FLC firms. All of the Central Coast FLCs we interviewed employed more than 200 workers during peak seasons and had payrolls of $\$ 2$ million, on average.

Commission rates varied by region. In the Imperial Valley, the average commission rate was $36 \%$. This dropped to $34.1 \%$ in the San Joaquin Valley. The majority of Central Coast FLCs used a straight commission of $11 \%$ or $12 \%$, which was added to payroll taxes. In general, Central Coast and Imperial Valley FLCs received higher commissions than those in the San Joaquin Valley. Again, these differences may be explained by the varying profitability of the agricultural sectors in these regions. The Central Coast and Imperial Valley are production centers for higher value crops (i.e., lettuce, strawberries and fresh vegetables) so the profit margins in these sectors may allow for higher labor bills, especially if quality work is a priority.

\section{TABLE 2. Reasons growers hire farm labor contractors}

\begin{tabular}{lccc}
\hline \hline Why growers hire FLCs & $\begin{array}{c}\text { FLC case study } \\
\text { participants* }\end{array}$ & $\begin{array}{c}1992 \text { EDD study } \\
\text { of 180 FLCs }\end{array}$ & $\begin{array}{r}1993 \text { Survey } \\
\text { of growers }\end{array}$ \\
\hline Reduce paperwork & 91 & 39 & $\%$ \\
Guarantee labor source & 9 & 10 & 18 \\
Lowers costs & 36 & 8 & 4 \\
Reduce liability & 55 & 7 & 28 \\
No supervision/ FLC meets worker's needs & 55 & 6 & 3 \\
FLCs are dependable & 91 & 4 & 2 \\
Good working relationship with FLCs & 91 & 1 & 4 \\
Concerns about IRCAf & 55 & NA & NA \\
Past labor disputes & NA & 4 & 6 \\
Handle timing of short-term employment & 0 & 2 & \\
Other & 27 & 20 & \\
\hline 'In this study, respondents were allowed to give more than one reason, so percentages are higher than for \\
the other two studies in which respondents were limited to one response. \\
†Thilmany (1994a), Chapter V. \\
flmmigration Reform and Control Act
\end{tabular}

While much of this regional variation may be due to farm size and crops grown, the level of enforcement provided in each region may also play a role. Government agencies seem to be most active in the Central Coast and Imperial Valley regions, updating both FLCs and growers through seminars conducted by the Employment Development Department and other agencies. The activities of these agencies in these regions may encourage growers to select "better" FLCs.

\section{Regulation}

Virtually all of the FLCs interviewed $(82 \%)$ indicated they had been visited in 1993 by labor law enforcement agencies cooperating in the Targeted Industries Partnership Program (TIPP). The federal-state program was begun in 1992 to educate employers and enforce labor laws in agriculture and the garment industry. Some had been inspected several times. Three of eight FLCs received citations for labor law violations, and one received a warning for a $50 \%$ rate of noncompliance.

The FLCs interviewed for this study may have been more likely to be inspected because of their size and visibility; however, this same size and visibility, as well as their willingness to be interviewed, also made them more likely to comply with labor laws. And yet, labor law violations seem to be widespread; the rate at which the 11 FLCs interviewed were cited or fined $(27 \%)$ in 1993 is not much below the $32 \%$ rate for FLCs fined or cited according to a statewide study conducted between 1987 and 1990 .

Some growers and FLCs believe TIPP helps "level the playing field" by enforcing labor laws, and thereby making it harder for FLCs who cheat to compete. FLCs and growers agreed that if growers thought they were either jointly or solely responsible for labor law violations, growers were more likely to carefully investigate their labor contractor.

\section{Conclusions}

California farmers are adjusting to an era of more regulations and increased liability for labor law and im- 


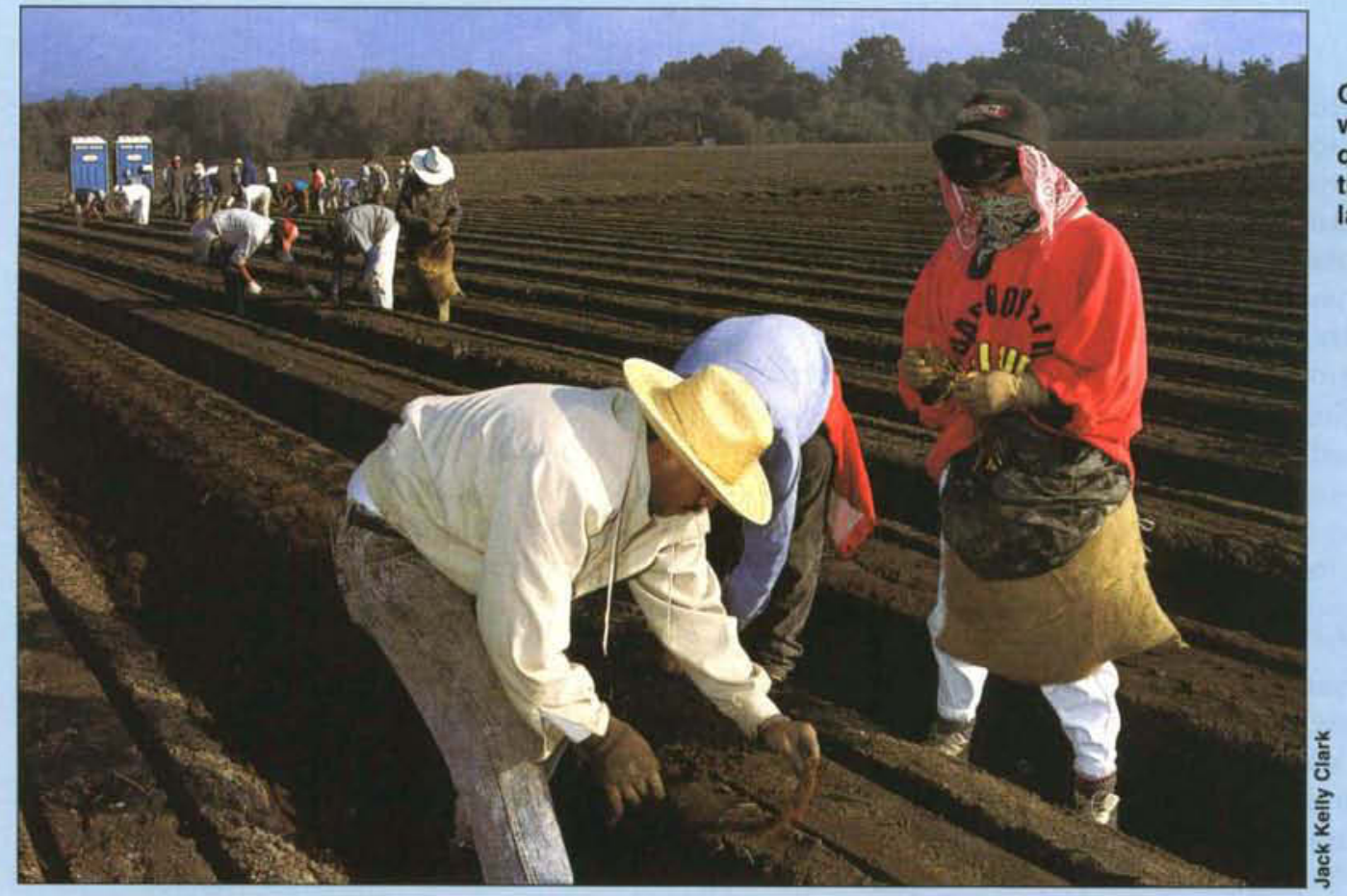

Growers often shift the paperwork and record-keeping required to comply with immigration and safety programs to farm labor contractors.

migration violations. They have done this in part by shifting recruitment and hiring responsibilities to FLC intermediaries. Labor contractors we interviewed said one reason that the FLC sector is expanding is the increasing number of farm labor regulations. Growers find it easier and cost-effective to turn labor recruitment and supervision over to FLCs than to deal with record-keeping and compliance themselves. This comparative advantage, which may have already existed, is more acute to growers in light of immigration reforms.

Yet the average FLC is no more prepared to uniformly comply with these regulations than are growers. FLCs express concern about increasing regulations, as well as inconsistencies in the enforcement of complex laws governing the farm labor sector.
However, grower concerns about liability have affected the relationships between growers and FLCs. Our survey suggests that there are still many growers who continue to believe that the use of FLCs frees them from liability for farm labor law violations. If labor laws were aggressively enforced and farmers were found to be liable for violations, it might enable reputable FLCs to charge higher commissions.

The grower/contractor pairs interviewed for this study are among some of the most financially successful operations in their industries and thus, may be considered innovators in adapting farm labor management to farm labor market conditions. To maintain successful business relationships, the growers and FLCs communicated regularly, were moving to- ward more formal written agreements, and were aware of one another's business practices and reputation. In this manner, growers reassured themselves that the FLC they used was in compliance with labor laws and the FLCs in compliance were sometimes, but not always, able to extract a small premium commission.

D. Thilmany is Assistant Professor, Utah State University; and P.L. Martin is Professor, UC Davis. This report is based on a project supported by the Agricultural Personnel Management Program entitled "An Assessment of Farm Labor Contractors' Business Management and Its Effects on the California Farm Labor Market." For further reading, see Commission on Agricultural Workers, 1992. Final Report. Washington: Government Printing Office.

\section{CALIFORNIA AGRICULTURE ASSOCIATE EDITORS}

\section{Animal, Avian, Aquaculture} and Veterinary Sciences (assoc. editors to be announced)

\section{Economics and Public Policy}

Harold O. Carter

Alvin Sokolow

\section{Food and Nutrition}

Barbara Schneeman

Eunice Williamson

Human and Community Development

Linda M. Manton

Karen P. Varcoe
Land, Air \& Water Sciences

J. Brian Mudd

Garrison Sposito

Henry J. Vaux, Jr.

Natural Resources

Daniel W. Anderson

John Helms

Richard B. Standiford

Pest Management

Michael Rust

Frank Zalom

Plant Sciences

Calvin O. Qualset

G. Steven Sibbett

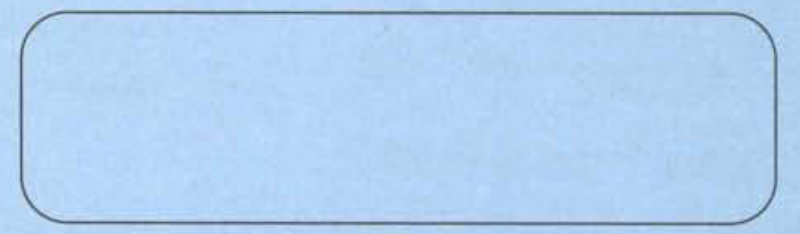

